\title{
Identification of potential sites for runoff water harvesting
}

1 Khamis Naba Sayl MSc, PhD

Associate Professor, Department of Dams and Water Resources, Engineering College, University of Anbar, Ramadi, Iraq; Department of Civil and Structural Engineering, Faculty of Engineering and Built Environment, Universiti Kebangsaan Malaysia, Selangor Darul Ehsan, Malaysia; (corresponding author: khamis.naba@gmail.com)

2 Nur Shazwani Muhammad MSc, BEng, PhD Senior Lecturer, Department of Civil and Structural Engineering, Faculty of Engineering and Built Environment, Universiti Kebangsaan Malaysia, Selangor Darul Ehsan, Malaysia
3 Ahmed El-Shafie MSc, PhD

Professor, Department of Civil Engineering, Faculty of Engineering, University of Malaya, Kuala Lumpur, Malaysia
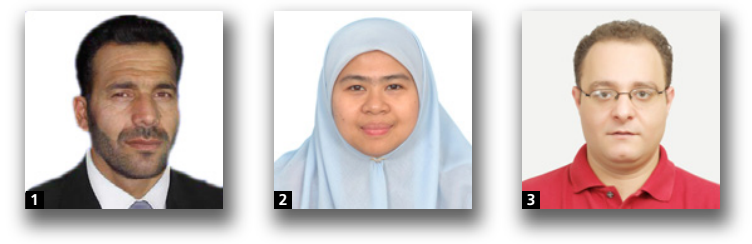

Runoff water harvesting (RWH) is a potential solution for areas suffering from water scarcity, such as the western desert of Iraq. Site selection based on RWH ranking using a combination of a watershed modelling system, geographic information systems and remote sensing techniques may enable authorities and water engineers to determine potential solutions to water scarcity. In this work, these methods were employed to produce eight thematic maps of the volume of annual floods, basin area, basin length, maximum flow distance, drainage frequency density, lineament frequency density, basin slope and stream order. These maps were used to rank and classify probable sites based on equal weight and statistical weight. The results were then used to classify the selected sites into four classes, namely sites with very high, high, moderate and low RWH potential. The proposed method was shown to be beneficial in the identification of potential RWH sites.

$\begin{array}{ll}\text { Notation } \\ P & \text { precipitation } \\ Q & \text { runoff depth } \\ R_{\mathrm{c}} & \text { average ranking } \\ S & \text { potential maximum retention after runoff starts } \\ W_{\mathrm{c}} & \text { equal weight } \\ W_{1 / v} & \text { statistical weight }\end{array}$

\section{Introduction}

The western desert of Iraq is an arid region facing great problems with regard to the availability of water resources (Adham et al., 2016; Reij et al., 1990; Sayl et al., 2017; Taffere et al., 2016). The harsh climate conditions and irregular precipitation in both space and time make water resources planning and management challenging. This area is therefore less populated and less developed than other areas in the country. The availability of a constant water supply, through proper planning and management of water resources, would enhance the overall quality of life in arid regions. In areas suffering from water scarcity, rainwater harvesting is considered to be one of the most significant ways of conserving water and improving life (Jha et al., 2014; Mahmoud, 2014).
Site selection for water harvesting in arid areas depends strongly on the meticulous planning of catchment basins to support human requirements. The formulation of appropriate management plans requires a large volume of accessible multidisciplinary data (Nooka Ratnam et al., 2005), including morphologic data (size and shape of the watershed, topography, drainage parameters etc.) and information on land use, land cover, soil and its characteristics, which affect the behaviour of the catchment. Therefore, the assessment of a variety of thematic resources for site selection can be a challenging task, especially for large watersheds. Tools such as geographic information systems (GIS) and remote sensing techniques can be employed to manage, analyse and assist site selection processes (Bonacci et al., 2006; Chowdary et al., 2009; Grohmann, 2004; Jamali et al., 2014; Jha et al., 2014; Kadam et al., 2012; Krois and Schulte, 2014; Pandey et al., 2011; Sayl et al., 2016; Singh, 1994). Morphometric analysis of a site provides a quantitative description of the drainage system, which is an important aspect in analysing and formulating targets for water resources development through runoff water harvesting (RWH). Most researchers utilise morphometric analysis for the development of water resources and management tasks, in addition to watershed characterisation and prioritisation (Javed et al., 2011; 
Kanth, 2010; Sarma and Saikia, 2012; Suresh et al., 2004; Thakkar and Dhiman, 2007).

Several researchers have recently suggested the method of prioritisation of watersheds for water harvesting using geometric parameter relationships. El Shamy (1992) discussed suitable controlling systems using obstacle stony dams in the upstream river of the hydrographic basin in Wadi ElArish. Using morphometric analysis to obtain potential runoff, Ashmawy et al. (2000) researched the risk of flash floods to drainage basins in Sinai. Aher et al. (2013) ranked watersheds through an investigation of drainage basins using a fuzzy analytical hierarchy process method. Their aim was to avoid the complexity of data linked with many morphological features by achieving superior accuracy in the prioritisation and identification of watersheds. Rahaman et al. (2015) investigated many morphological features and the application of GIS and fuzzy analytical hierarchy processes to identify critical subwatersheds of Kallar, Tamil Nadu.

In the work reported in this paper, a methodology for RWH site selection was developed by integrating remote sensing, a watershed modelling system (WMS) and GIS. RWH site selection was based on hydrological and hydro-morphometric criteria. Eight thematic maps were developed, namely, the volume of annual floods, basin area, basin length, maximum flow distance, drainage frequency density, lineament frequency density, basin slope and stream order. Additionally, two methods of weighting criteria (equal weight $W_{\mathrm{c}}$ and statistical weight $W_{1 / v}$ ) were compared in order to rank and determine the best RWH sites.

\section{Methodology}

Figure 2 shows a flowchart of the methodology. Visual interpretation of satellite images was used for site selection, based on the width of valleys, the height of tenacious walls, valley slopes and narrow canyons. These characteristics allowed the use of the location's natural features to support site selection. The interpretation of Landsat 8 satellite images from 2013 using Erdas Imagine 9.3 and geological maps were used to extract the lineaments. A QuickBird satellite image (2006) and digital elevation model (DEM) of $30 \mathrm{~m}$ extracted from the Shuttle Radar Topographic Mission (SRTM) were used as input data (Figure 1). As a result, a total of 32 potential RWH sites were selected for calculation of hydrological and hydro-morphological parameters. The SRTM DEM was consequently improved by both ground control points and the height of spots.

For each site, the geometric parameters of the catchment area were deduced using the WMS software Aquaveo. This software defined the basins and afforded numerous features for each catchment. Eight thematic maps - volume of annual flood, basin area, basin length, basin slope, maximum flow distance, drainage frequency density, lineament frequency density and stream order - were extracted in order to determine potential sites for
RWH. Aquaveo software was used to compute the hydromorphometric features for each watershed, as listed in Table 1. The ArcGIS 10.2 software spatial analyst model used layer manipulation. A geological map of the study area was utilised to identify types of soil. The Soil Conservation Service curve number (SCS-CN) model was used to calculate runoff (Elewa et al., 2012; Hogarth et al., 2004; Jain and Sinha, 2003; Tyagi et al., 2008). The maximum discharges were calculated by Aquaveo using storm data, the DEM and land use/cover and soil data, where the $\mathrm{CN}$ was generated. The environmental features related to rainfall-runoff were estimated using the SCS-CN technique. The runoff depth was calculated using (Maidment, 1992)

$$
\text { 1. } Q=\frac{(P-0 \cdot 2 S)^{2}}{(P+0 \cdot 8 S)}
$$

2. $S=\frac{25400}{\mathrm{CN}}-254$

where $Q$ is the runoff depth (in $\mathrm{mm}$ ), $S$ is the potential maximum retention after runoff starts $(\mathrm{mm}), P$ is precipitation $(\mathrm{mm})$ and $\mathrm{CN}$ is the runoff curve number.

To determine the suitability of sites for RWH, hydro-morphometric criteria were considered. Many researchers have found that hydro-morphometric criteria are highly correlated with runoff volume and peak discharge (Elewa et al., 2012; Gregory and Walling, 1985). The main criteria (volume of annual flood, basin area, basin length, maximum flow distance, drainage frequency density, lineament frequency density, basin slope and stream order) were deduced to determine effective sites for RWH (Table 1) using GIS thematic maps.

Using the prepared GIS maps, ranking and classification processes were developed based on two methods of weighting criteria. In the first method, rates and weights were estimated and identified depending on the judgements of previous researchers (Elewa et al., 2012; Mohd Hasmadi et al., 2010; Sadrolashrafi et al., 2008). Hence, all the criteria were given equal weight $\left(W_{\mathrm{c}}=0 \cdot 125\right)$ in the ranking and classification processes. In the second method, the statistical method of the inverse of the variance value $\left(W_{1 / v}\right)$ was used to provide criteria weighting. This method defines the variance as the square of the variation between the site criterion value and the best value of the criterion for all sites. The basin slope and lineament frequency density work negatively in RWH sites. Therefore, these were taken as the inverse for each value, with lowest value representing the highest RWH potential. The other criteria are positive.

With reference to Table 1 , the values of the criteria are not on the same scale. Therefore, it was necessary to convert the 


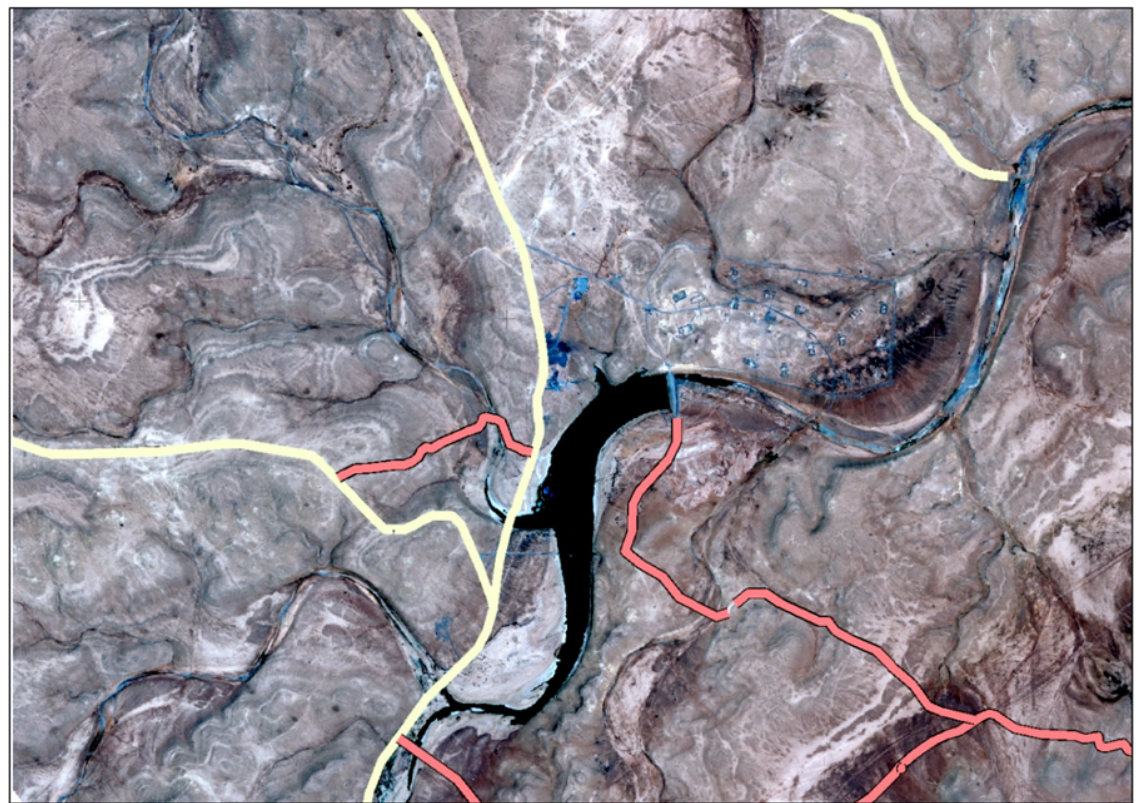

(a)

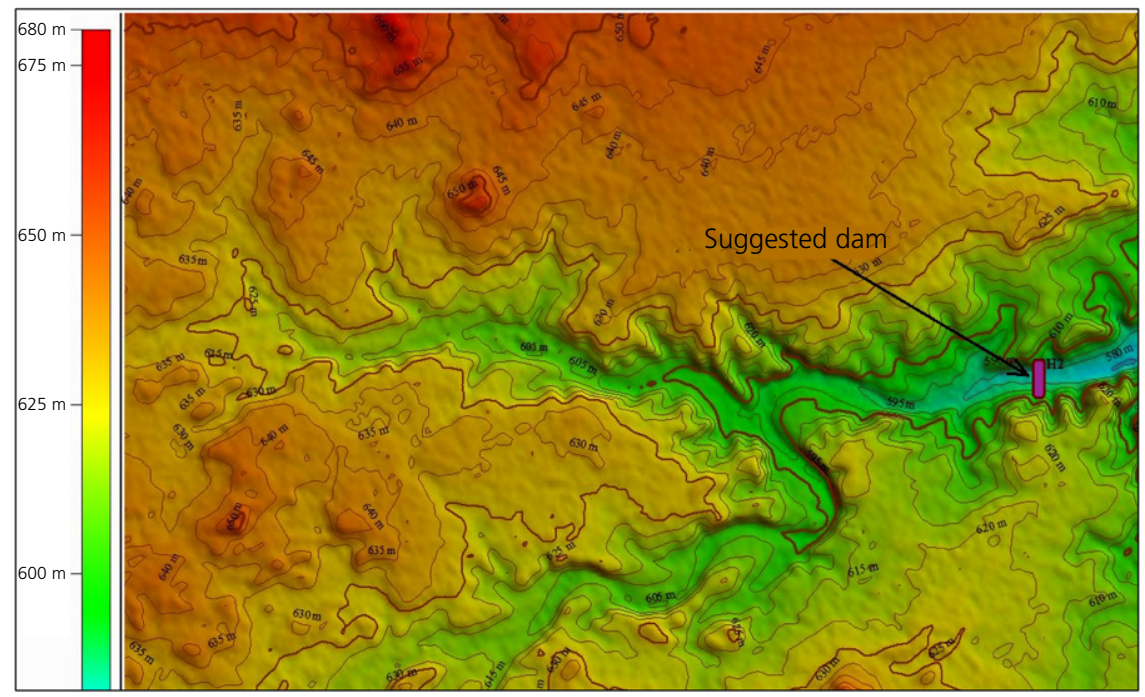

(b)

Figure 1. (a) QuickBird satellite image. (b) DEM

criteria to a standardised scale before starting the weighting process. Normalisation was performed by assigning the same dimensionless continuous scale, from 0 to 1 . The statistical weighting $\left(W_{1 / v}\right)$ of each criterion, that is, basin area, basin length, maximum flow distance, volume of annual runoff, stream order, drainage frequency density, slope basin and lineament frequency density was $0 \cdot 15,0 \cdot 13,0 \cdot 13,0 \cdot 12,0 \cdot 17$, $0 \cdot 13,0.11$ and 0.06 respectively. The maximum rate of $\mathrm{RWH}$ was considered to be $100 \%$, with five classes of $0-20 \%, 20$ $40 \%, 40-60 \%, 60-80 \%$ and $80-100 \%$. Therefore, the average ranking, $R_{\mathrm{c}}$, for each class is $10,30,50,70$ and $90 \%$, respectively. Based on the ranking and classifying process using the two methods of weighting criteria, the selected sites in the study area were classified into classes of RWH potential.

\section{Study area}

The study area is Wadi Horan, which is the largest valley in the western desert of Iraq. This valley lies south of the Euphrates River, with geographic coordinates $32^{\circ} 10^{\prime} 44^{\prime \prime}$ to $34^{\circ}$ $11^{\prime} 00^{\prime \prime} \mathrm{N}$ (latitude) and $39^{\circ} 20^{\prime} 00^{\prime \prime}$ to $42^{\circ} 30^{\prime} 00^{\prime \prime} \mathrm{E}$ (longitude), as shown in Figure 3. The total length of Wadi Horan is $362 \mathrm{~km}$, with a catchment area of $13370 \mathrm{~km}^{2}$, a width of $49 \cdot 3 \mathrm{~km}$, a perimeter of $1307 \mathrm{~km}$ and a shape coefficient of $0 \cdot 13$. The area suffers from severely arid climate conditions. 


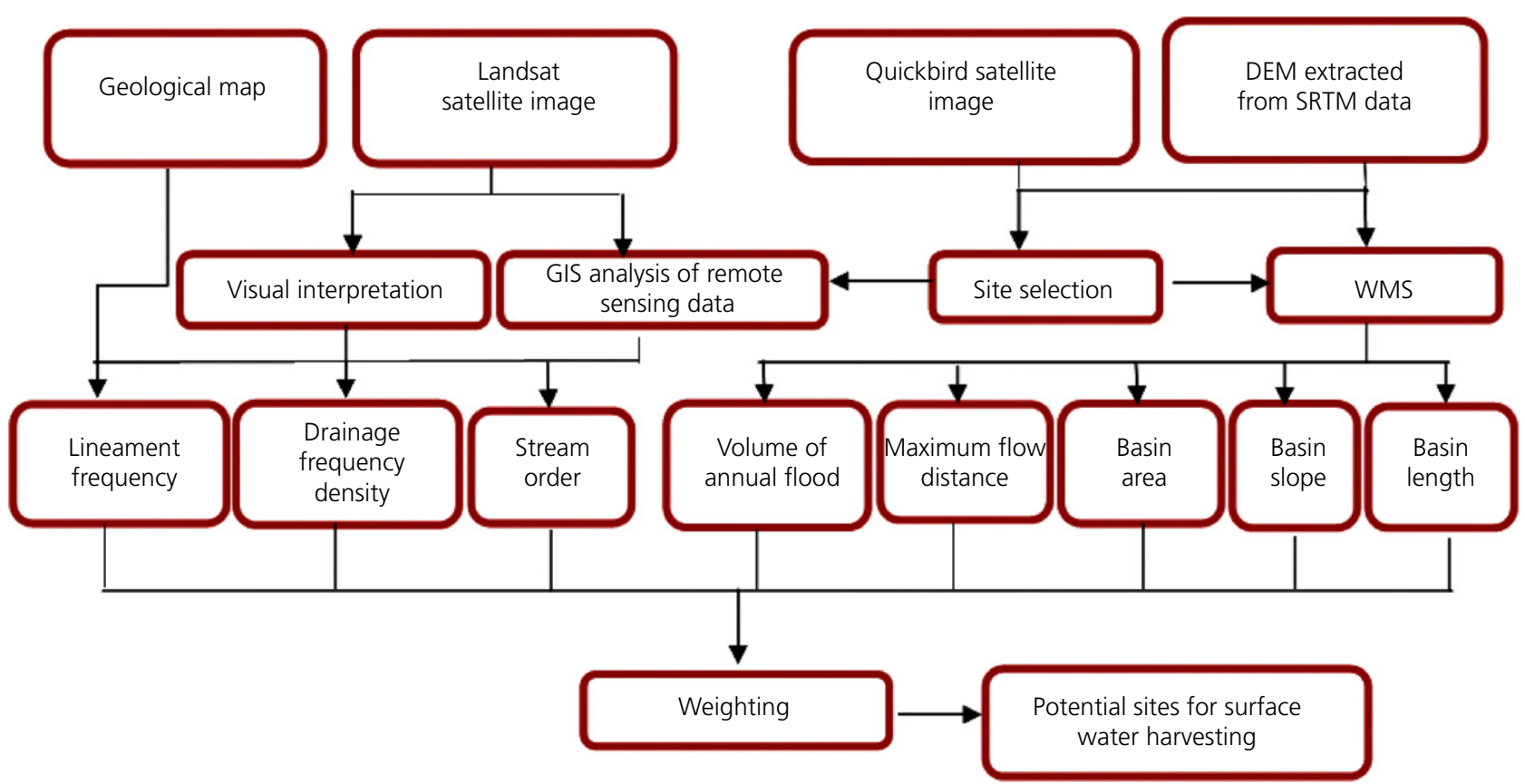

Figure 2. Flowchart of methodology

Table 1. Hydro-morphometric criteria extracted by WMS

\begin{tabular}{|c|c|c|c|c|c|c|c|}
\hline Site & $\begin{array}{l}\text { Longitude (E): } \\
\text { degrees }\end{array}$ & $\begin{array}{l}\text { Latitude }(\mathrm{N}) \text { : } \\
\text { degrees }\end{array}$ & $\begin{array}{l}\text { Basin area: } \\
\text { km }^{2}\end{array}$ & $\begin{array}{c}\text { Basin } \\
\text { length: } \mathrm{km}\end{array}$ & $\begin{array}{l}\text { Basin } \\
\text { slope }\end{array}$ & $\begin{array}{l}\text { Maximum flow } \\
\text { distance: } m\end{array}$ & $\begin{array}{l}\text { Annual flood: } \mathrm{m}^{3} / \text { year } \\
\text { (SCS-CN method) }\end{array}$ \\
\hline 1 & $42 \cdot 42144$ & 33.92855 & 12543 & 351767 & 0.0176 & 491165 & 951899649 \\
\hline 2 & $42 \cdot 25638$ & $33 \cdot 86908$ & 12385 & 335519 & 0.0176 & 470173 & 939732697 \\
\hline 3 & $42 \cdot 18277$ & $33 \cdot 87777$ & 12095 & 330386 & 0.0176 & 461863 & 917682600 \\
\hline 4 & $42 \cdot 10432$ & $33 \cdot 89357$ & 11998 & 325139 & 0.0176 & 449849 & 910327731 \\
\hline 5 & $42 \cdot 03424$ & 33.89789 & 11935 & 320315 & 0.0176 & 442241 & 905545272 \\
\hline 6 & 41.99692 & 33.90625 & 11874 & 317317 & 0.0175 & 437469 & 900970961 \\
\hline 7 & $41 \cdot 77822$ & $33 \cdot 81171$ & 10928 & 294935 & 0.0178 & 406074 & 826541205 \\
\hline 8 & $41 \cdot 72391$ & $33 \cdot 80540$ & 10893 & 290870 & 0.0177 & 400406 & 826541212 \\
\hline 9 & $41 \cdot 61457$ & $33 \cdot 75036$ & 10596 & 279693 & 0.0179 & 387682 & 803956977 \\
\hline 10 & $41 \cdot 50907$ & $33 \cdot 69491$ & 10535 & 267748 & 0.0177 & 373872 & 797018435 \\
\hline 11 & $41 \cdot 43116$ & $33 \cdot 64195$ & 10463 & 258639 & 0.0176 & 363646 & 794282672 \\
\hline 12 & $41 \cdot 36391$ & $33 \cdot 64339$ & 10358 & 253998 & 0.0177 & 356389 & 785912177 \\
\hline 13 & $41 \cdot 24602$ & $33 \cdot 58462$ & 10158 & 241223 & 0.0176 & 340876 & 774256594 \\
\hline 14 & $41 \cdot 19207$ & $33 \cdot 56646$ & 9844 & 235686 & 0.0178 & 333838 & 746931250 \\
\hline 15 & $41 \cdot 08821$ & $33 \cdot 54545$ & 9702 & 227290 & 0.0178 & 323034 & 736123933 \\
\hline 16 & $41 \cdot 01743$ & $33 \cdot 52603$ & 9059 & 221128 & 0.0174 & 313872 & 687345674 \\
\hline 17 & $40 \cdot 96254$ & $33 \cdot 48766$ & 8723 & 214525 & 0.0173 & 306152 & 661910036 \\
\hline 18 & $40 \cdot 87706$ & $33 \cdot 41605$ & 8630 & 201566 & 0.0172 & 310034 & 65365080 \\
\hline 19 & $40 \cdot 84494$ & $33 \cdot 38292$ & 8552 & 198594 & 0.0171 & 283267 & 648897907 \\
\hline 20 & $40 \cdot 71420$ & $33 \cdot 32392$ & 8172 & 186181 & 0.0168 & 264248 & 620048848 \\
\hline 21 & $40 \cdot 68003$ & $33 \cdot 30662$ & 8081 & 180517 & 0.0167 & 257002 & 613156300 \\
\hline 22 & $40 \cdot 89329$ & $33 \cdot 49887$ & 462 & 32399 & 0.0194 & 42126 & 18873111 \\
\hline 23 & 41.03449 & $33 \cdot 42040$ & 498 & 48328 & 0.0260 & 64541 & 18221821 \\
\hline 24 & $40 \cdot 63865$ & $33 \cdot 32663$ & 386 & 17594 & 0.0188 & 22872 & 8107106 \\
\hline 25 & $40 \cdot 61890$ & $33 \cdot 26507$ & 351 & 34166 & 0.0147 & 47024 & 18200045 \\
\hline 26 & $40 \cdot 47635$ & $33 \cdot 13571$ & 6885 & 154581 & 0.0162 & 223684 & 522416514 \\
\hline 27 & $40 \cdot 40570$ & $33 \cdot 10345$ & 6659 & 147217 & 0.0159 & 214883 & 505291250 \\
\hline 28 & $40 \cdot 31074$ & $33 \cdot 06174$ & 5693 & 137755 & 0.0152 & 199302 & 452430733 \\
\hline 29 & $40 \cdot 06835$ & $32 \cdot 94038$ & 5090 & 113246 & 0.0125 & 167249 & 386211497 \\
\hline 30 & $40 \cdot 03646$ & $32 \cdot 88597$ & 4741 & 159906 & 0.0118 & 167130 & 359743793 \\
\hline 31 & $40 \cdot 23177$ & $32 \cdot 87280$ & 623 & 25694 & 0.0274 & 37151 & 30997066 \\
\hline 32 & 39.99599 & $32 \cdot 82596$ & 4676 & 100894 & 0.0114 & 152656 & 78920084 \\
\hline
\end{tabular}




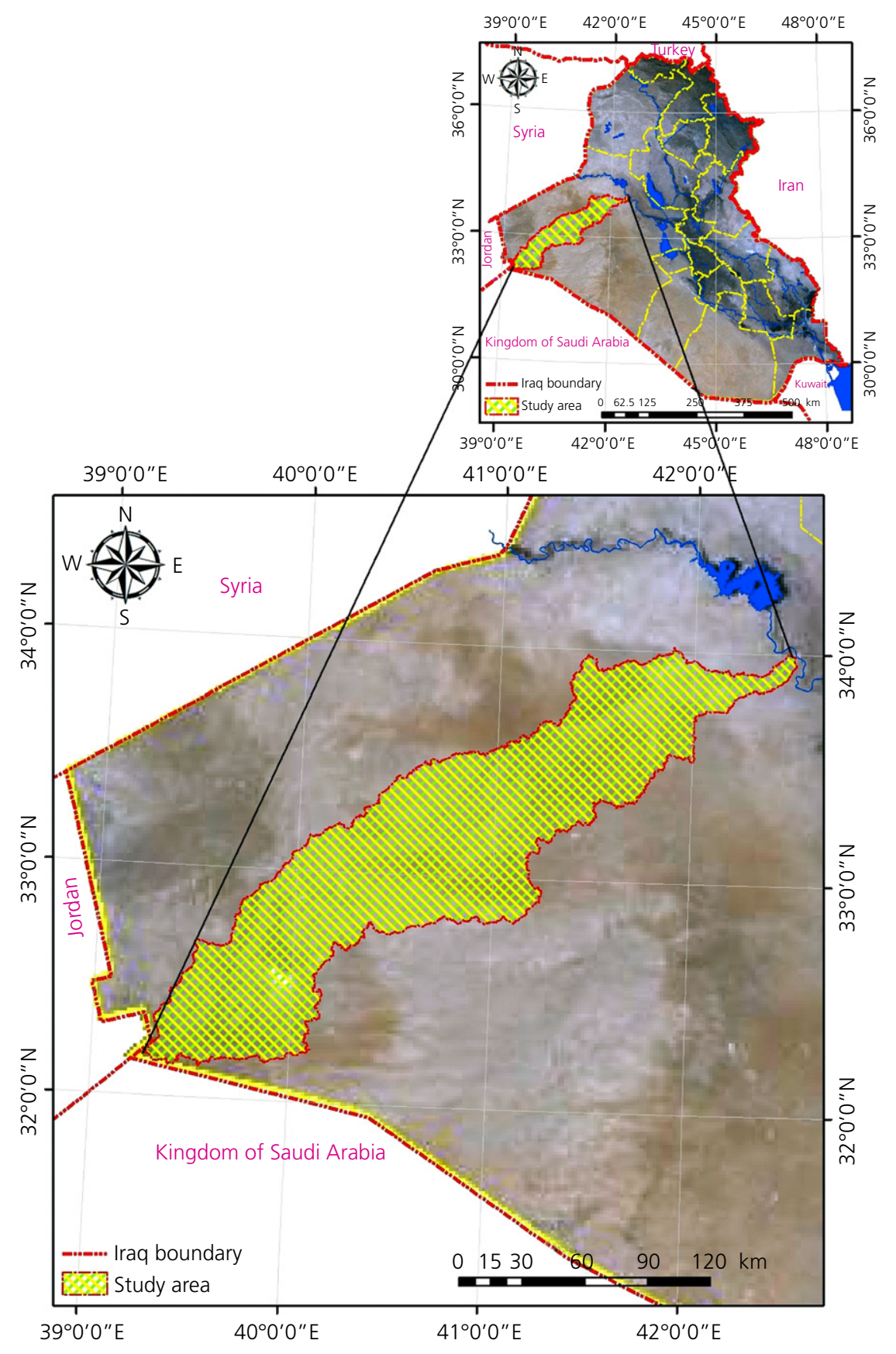

Figure 3. Study area map

The key climate characteristics of the study area include tremendously low and uneven rainfall. The area is cold in winter and very hot in summer, with great seasonal and diurnal temperature differences. The maximum average annual temperature, typically recorded in July and August, is $42 \cdot 8^{\circ} \mathrm{C}$. The lowest average annual temperature is $2 \cdot 6^{\circ} \mathrm{C}$, typically recorded in December to February. The months of June to September are the dry season in the area, whereas the rainy season covers December to May; the average annual rainfall is $115 \mathrm{~mm}$. The mean record annual runoff is 900 million $\mathrm{m}^{3}$, while the annual mean of relative humidity, which varies from month to month throughout the year, is about $46 \cdot 2 \%$. The average annual evaporation rate is estimated to be about $3200 \mathrm{~mm}$, with a dryness coefficient between 25 and 35 . The area is characterised by a deep groundwater level with no recharge to the surface runoff, and hence some artesian wells have developed in the area (Kamel and Mohammed, 2010). 
A slight change in elevation was deduced for the topography of the catchment area, with a moderate slope to the Euphrates River valley. A height difference of only $600 \mathrm{~m}$ was recorded between the start and end of the catchment. Sandstones available in the area could be used as a suitable base for dam construction.

\section{Results and discussion}

The previously mentioned criteria were transformed into ready to use data in GIS for storage and manipulation after describing the basin characteristics inside the platform of the WMS with the DEM. The range of each criterion was manipulated in GIS thematic maps. Based on the rating and weighting method, the incorporation of all criteria in the GIS produces maps to identify suitable RWH sites. The eight thematic maps developed using the methodology proposed in the previous section are now discussed.

\subsection{Volume of annual runoff}

The success of RWH depends strongly on the quantity of water that can be collected under the given climatic conditions. Rainfall data covering the period 1941 to 2013 were used to calculate the annual runoff volume using the SCS-CN method. The thematic map of annual runoff volume for the study area is shown in Figure 4(a). There are five classes of potential RWH: very high (>900 million $\mathrm{m}^{3} / \mathrm{year}$ ), high (700-900 million $\mathrm{m}^{3} /$ year), moderate (500-700 million $\mathrm{m}^{3} /$ year), low (300-500 million $\left.\mathrm{m}^{3} / \mathrm{year}\right)$ and very low ( $<300$ million $\mathrm{m}^{3} /$ year). As shown in Figure 4(a), the highest classification of annual runoff ( $>900$ million $\mathrm{m}^{3} / \mathrm{year}$ ) was observed in the northeast of the study area whereas sites with very low and low classes of annual runoff volume were identified in the southwestern parts of the study area.

\subsection{Lineament frequency density}

Analysis of lineament frequency density is significant for the mapping of potential RWH sites as fractures and joints increase infiltration of the soil. Hence, the higher the lineament frequency density, the lower the RWH potential. Visual interpretation of Landsat 8 satellite imagery (acquired in 2013) was used to extract lineament frequency density, which was confirmed by comparing with lineaments and structures shown on the geological map. The density of lineament frequency was determined by categorising the area into $20 \mathrm{~km}$ by $20 \mathrm{~km}$ frames.

The resulting lineament frequency density map is shown in Figure 4(b). Five classes were assigned for RWH potential: very low (11-13 lineaments per $\left.400 \mathrm{~km}^{2}\right)$, low (9-11 lineaments per $\left.400 \mathrm{~km}^{2}\right)$, moderate $\left(6-8\right.$ lineaments per $\left.400 \mathrm{~km}^{2}\right)$, high (3-5 lineaments per $\left.400 \mathrm{~km}^{2}\right)$ and very high $(<3$ lineaments per $400 \mathrm{~km}^{2}$ ). Northeastern and central parts of the study area showed low lineament frequency density and therefore high potential for RWH. The sites that occupied a very low and low lineament frequency density were in the southwestern part of the study area (Figure 4(b)).

\subsection{Drainage frequency density}

A Landsat 8 satellite image was used to prepare the drainage network map. Analysis of drainage frequency density has significant importance for RWH potential as the amount of runoff losses through infiltration are affected by the drainage frequency density: the lower the drainage frequency density, the lower the RWH potential. A drainage frequency density map in terms of the number of streams per $20 \mathrm{~km}$ by $20 \mathrm{~km}$ area was constructed. The resulting map is shown in Figure 5(a), with five divisions of drainage frequency density: very low (22-26 streams per $\left.400 \mathrm{~km}^{2}\right)$, low (26-30 streams per $\left.400 \mathrm{~km}^{2}\right)$, moderate (30-34 streams per $\left.400 \mathrm{~km}^{2}\right)$, high (34-38 streams per $400 \mathrm{~km}^{2}$ ) and very high (>38 streams per $400 \mathrm{~km}^{2}$ ). The mean stream frequency density for the study area was determined to be $0.61 \mathrm{~km}^{2}$. As shown in Figure 5(a), a very high drainage frequency density was found in the central part of the study area, with very low drainage frequency density class in the northeastern part.

\subsection{Stream order}

Stream order is based on the connection of tributaries. The order of streams is used to denote hierarchical connections among stream segments and permits drainage basins to be categorised according to their size. Analysis of the stream order has significant meaning for mapping RWH potential: a lower stream order results in higher permeability and infiltration. Moreover, dendritic drainage patterns shaped by the linking of streams indicate homogeneity in texture and a lack of structural control. In the resulting map of stream order (Figure 5(b)), potential RWH sites were classified as having very low stream order (<fourth order), low (fifth order), moderate (sixth order), high (seventh order) and very high (>seventh order). The highest stream order (eighth order) was observed in the northeastern part of the study, and this area thus represents very high RWH potential. The total length of the highest stream order was $80 \mathrm{~km}$. The total length of the very low class (fourth order) was $890 \mathrm{~km}$. In total 144 fourth-order streams, 13 fifth-order streams, four sixth-order streams, two seventh-order streams and one eighth-order stream were observed among the 11034 streams in the study area.

\subsection{Maximum flow distance}

Horton (1945) defined the maximum flow distance as the maximum distance of the water path in a drainage basin. For a drainage basin, the maximum flow distance is vital in defining RWH potential, with a higher maximum flow distance indicating the higher probability of available sites for RWH. In addition, the maximum flow distance is a function of basin area. Figure 6(a) shows the resulting thematic map of the maximum flow distance factor, which was classified as very low $(<100000 \mathrm{~m})$, low $(100000-250000 \mathrm{~m})$, moderate 


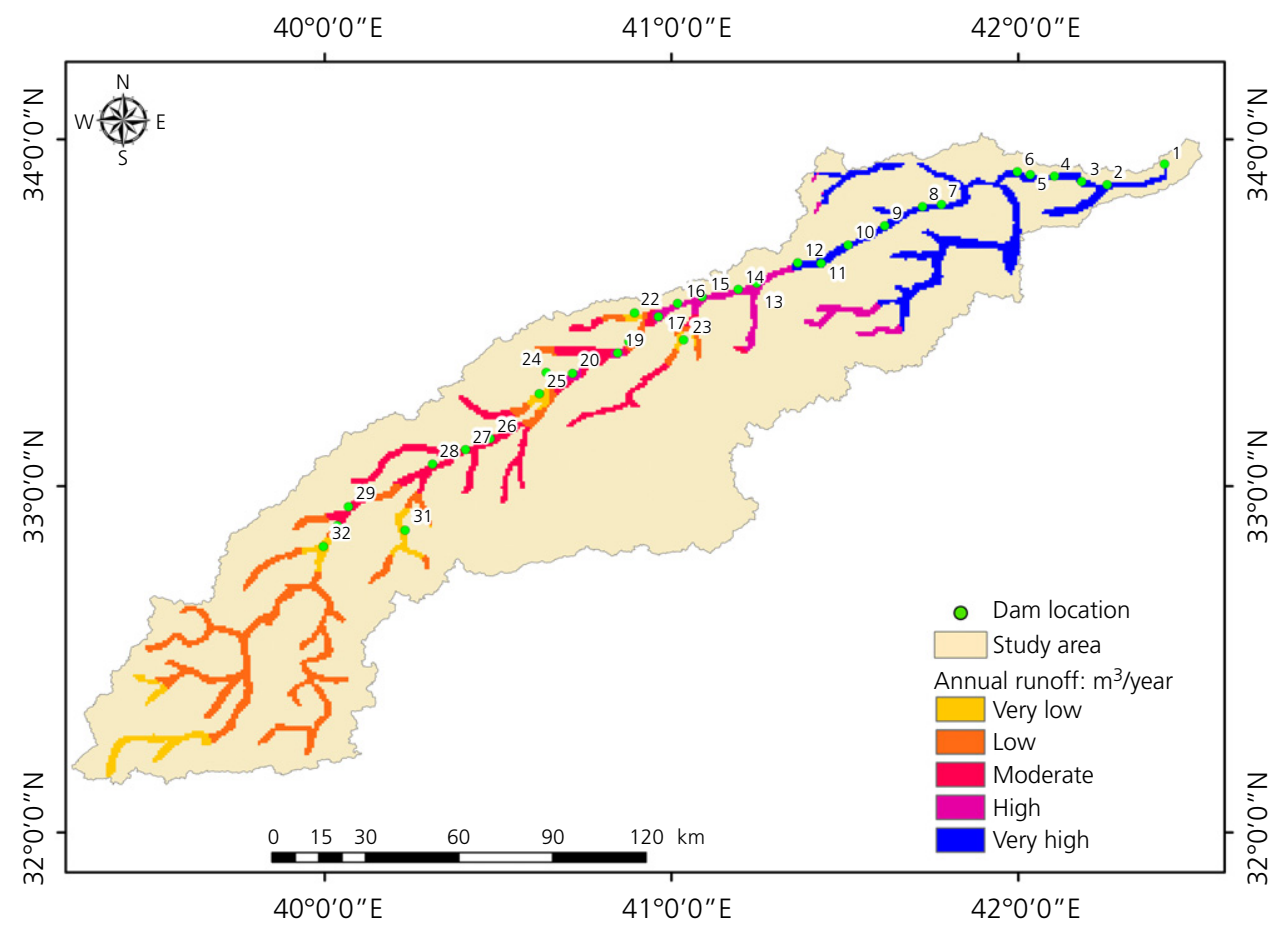

(a)

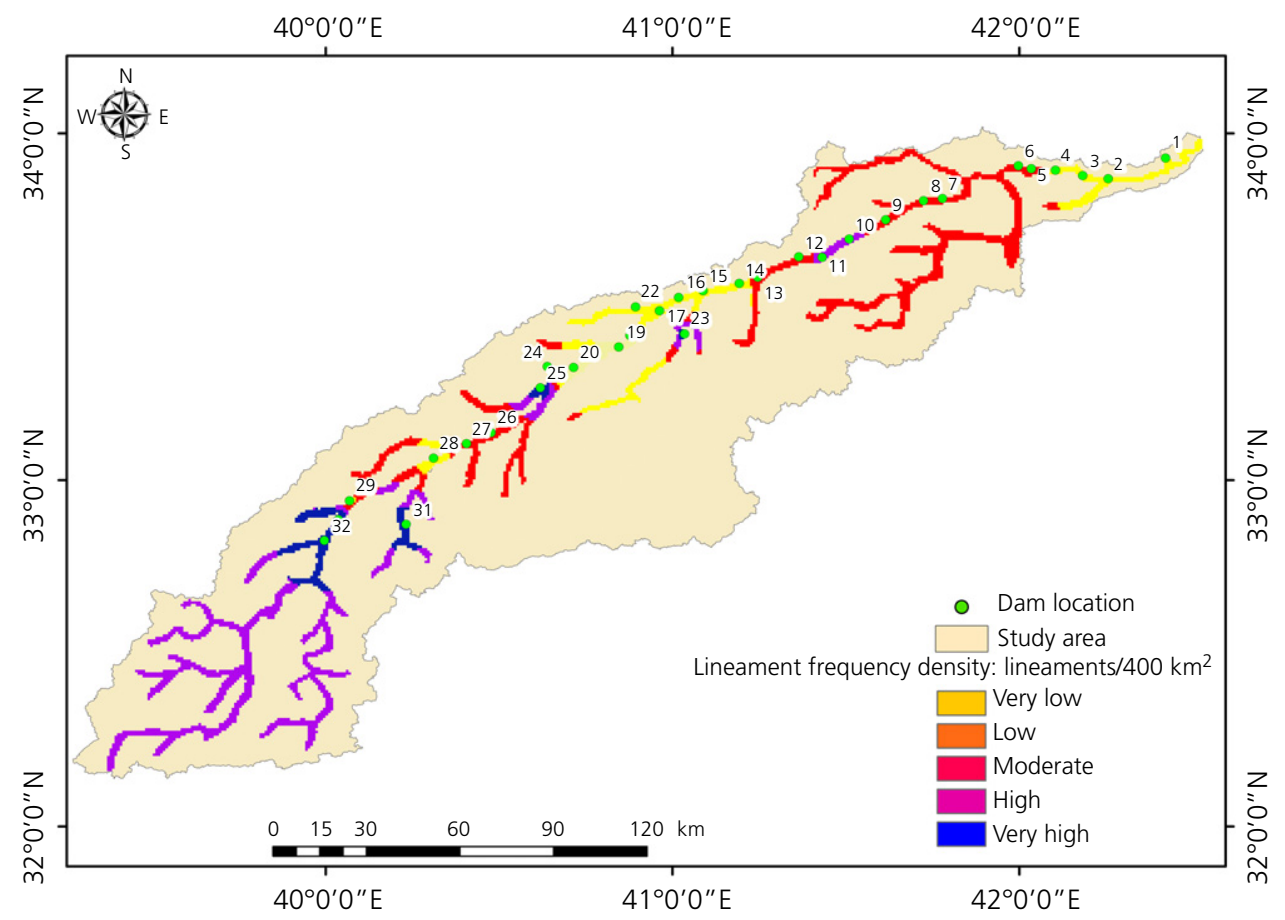

(b)

Figure 4. Thematic maps of (a) annual runoff volume and (b) lineament frequency density. A full-colour version of this figure can be found on the ICE Virtual Library (www.icevirtuallibrary.com)

(250 000-300 $000 \mathrm{~m})$, high (300 000-400 000) and very high (>400 $000 \mathrm{~m}$ ). Very high and high classes of the maximum flow distance are in the northeastern part of the study area, with the moderate class comprising a large portion of the study area. The very low class of maximum flow distance occurred in the southwestern part of the study area. 


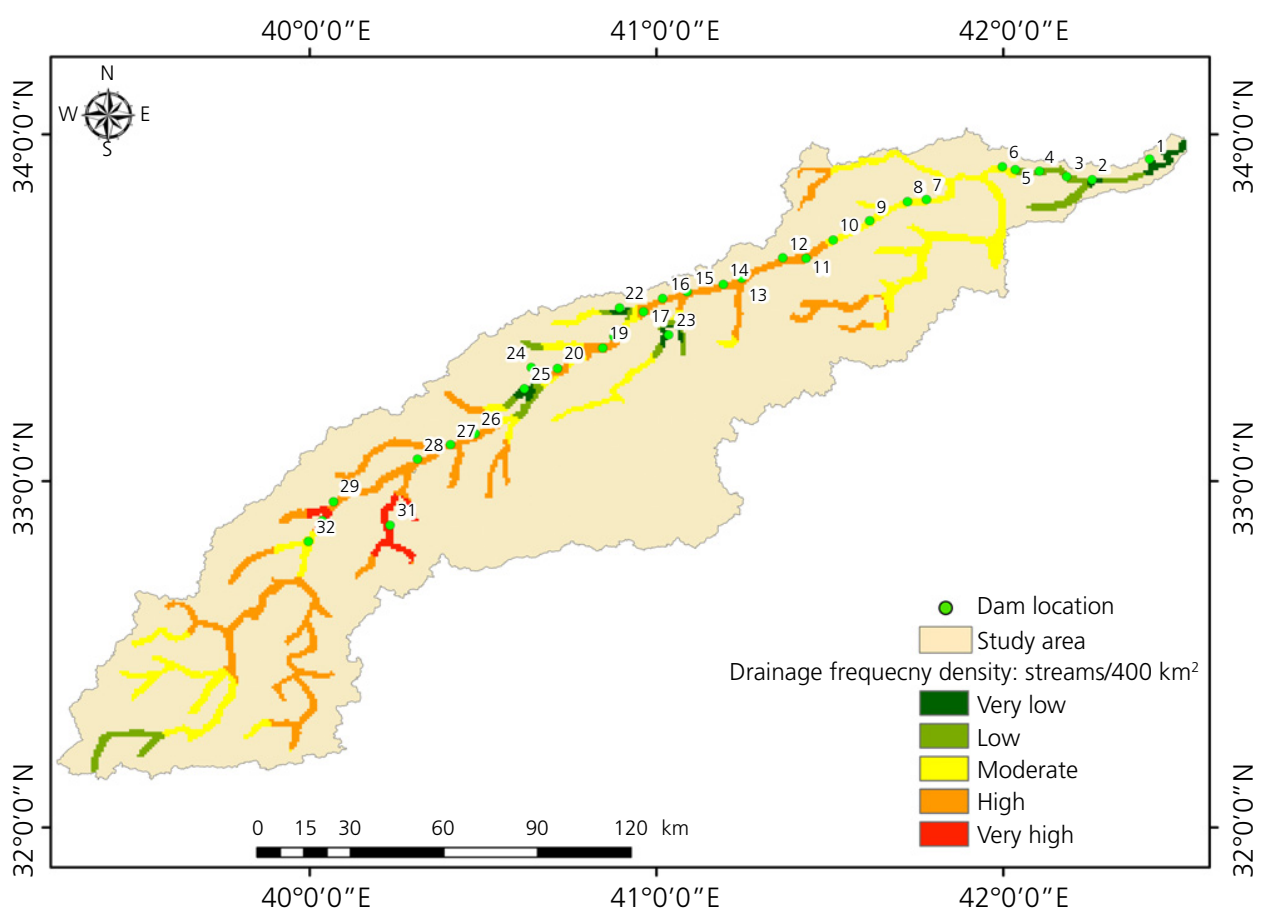

(a)

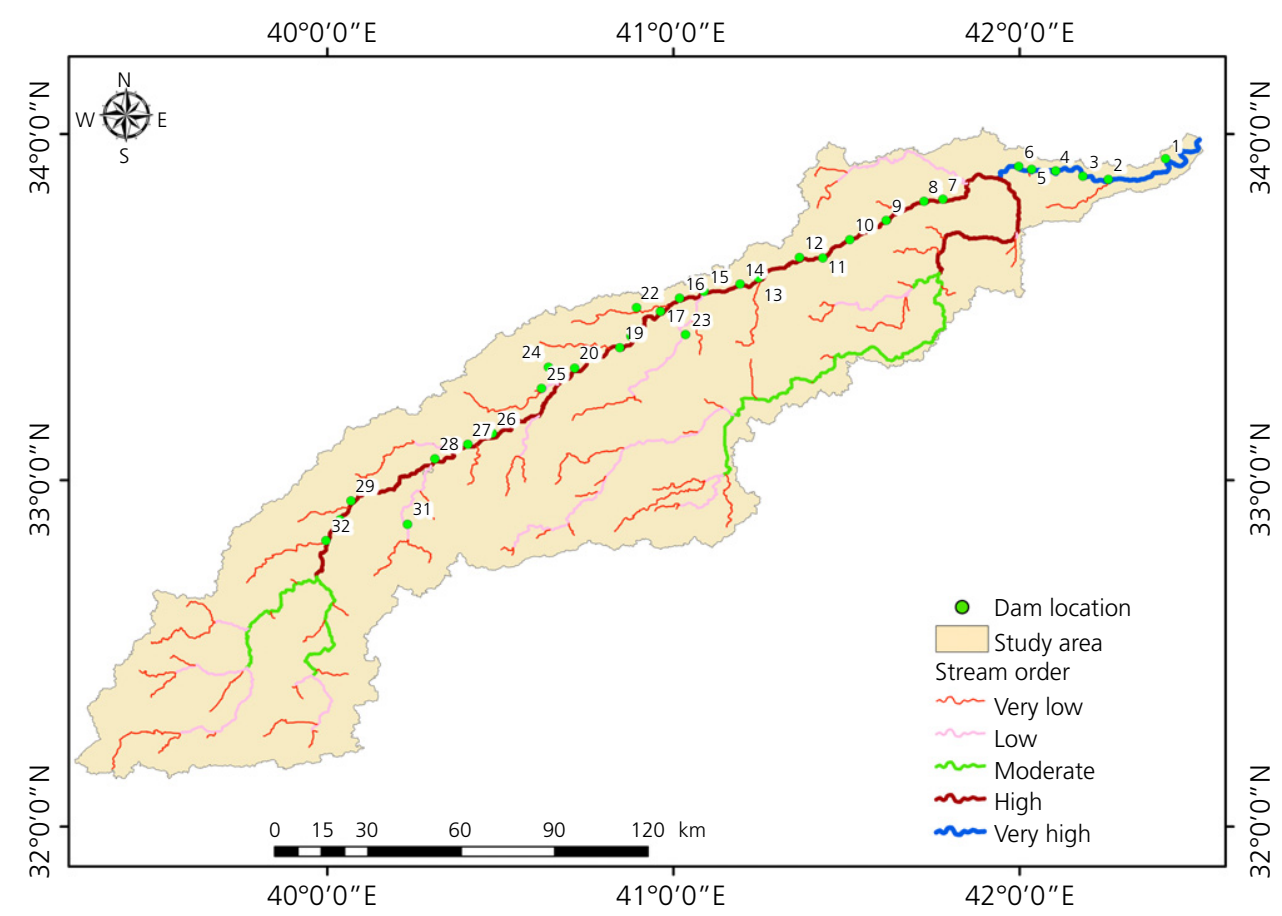

(b)

Figure 5. Thematic maps of (a) drainage frequency density and (b) stream order. A full-colour version of this figure can be found on the ICE Virtual Library (www.icevirtuallibrary.com)

\subsection{Basin area}

Basin area represents the total land area bounded by basin borders (Horton, 1945). It is recognised as a vital hydro-morphometric criterion for guiding watershed runoff patterns, attributable to greater volumes of rainfall resulting in higher peak discharges (Pitlick, 1994). Additionally, basin area 


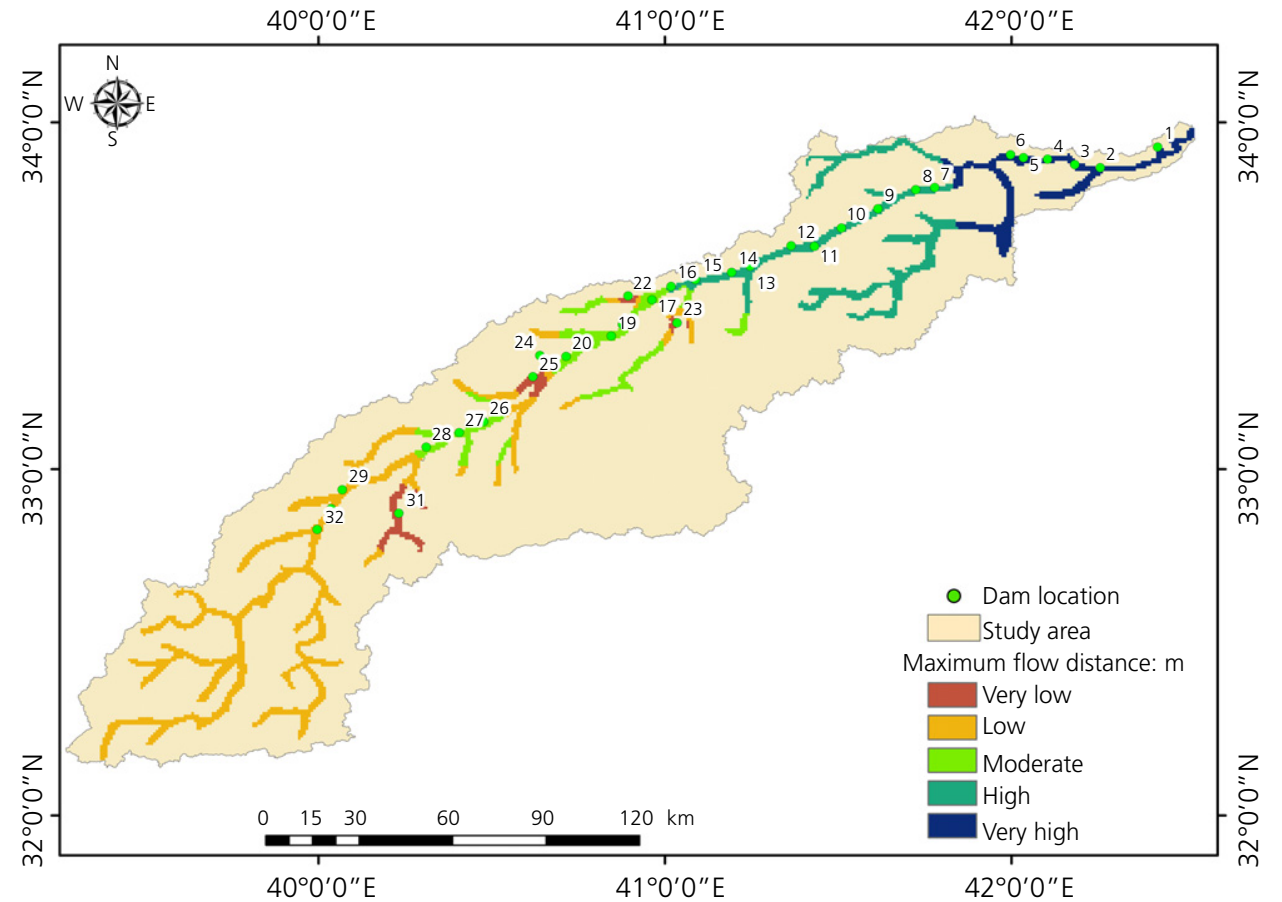

(a)

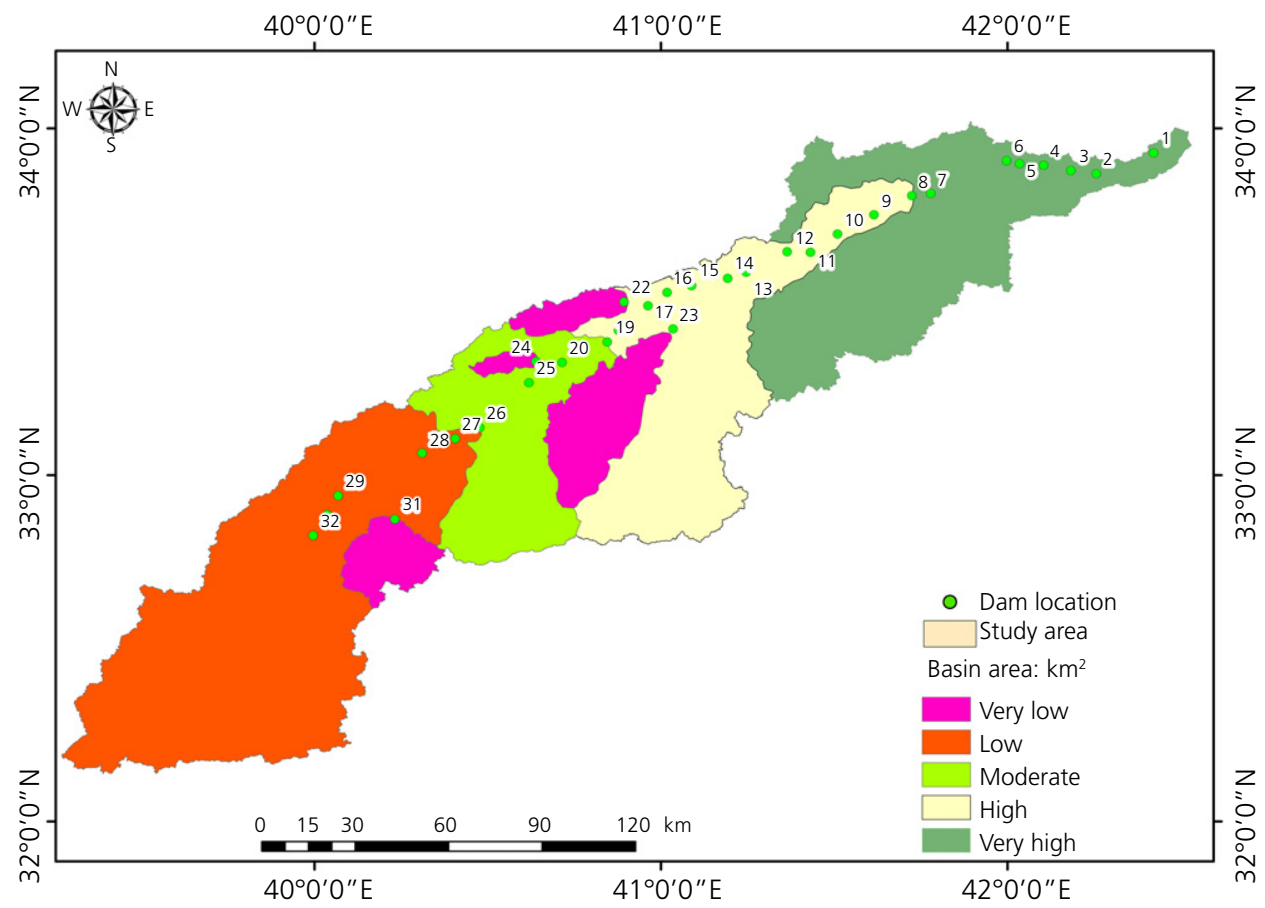

(b)

Figure 6. Thematic maps of (a) maximum flow distance and (b) basin area. A full-colour version of this figure can be found on the ICE Virtual Library (www.icevirtuallibrary.com)

is strongly associated with other watershed morphometric features that affect surface runoff (i.e. maximum flow distance and basin length).
The thematic map (Figure 6(b)) shows five classes for basin area: very low $\left(<1000 \mathrm{~km}^{2}\right)$, low $\left(1000-8000 \mathrm{~km}^{2}\right)$, moderate $\left(8000-9000 \mathrm{~km}^{2}\right)$, high $\left(9000-10000 \mathrm{~km}^{2}\right)$ and very high 


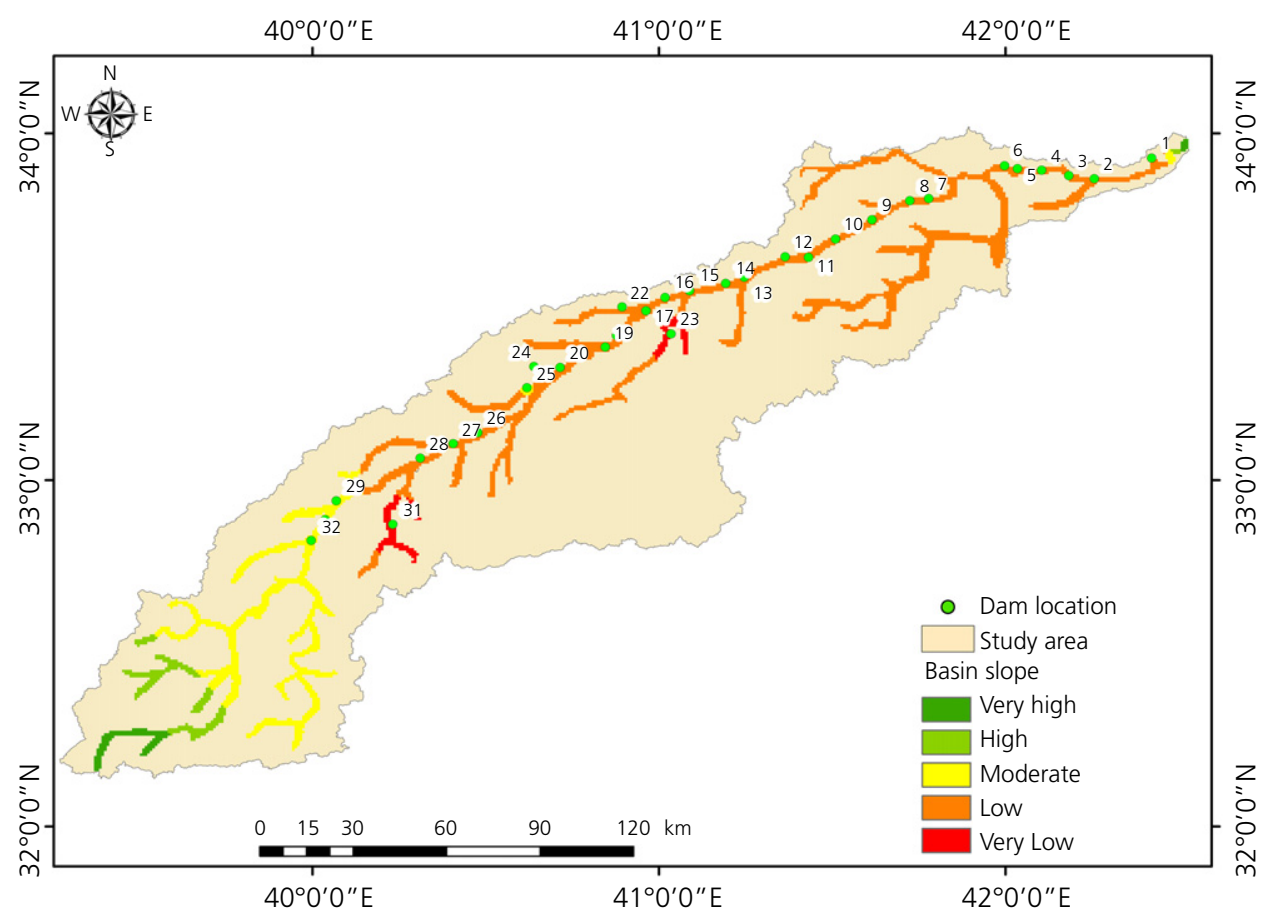

(a)

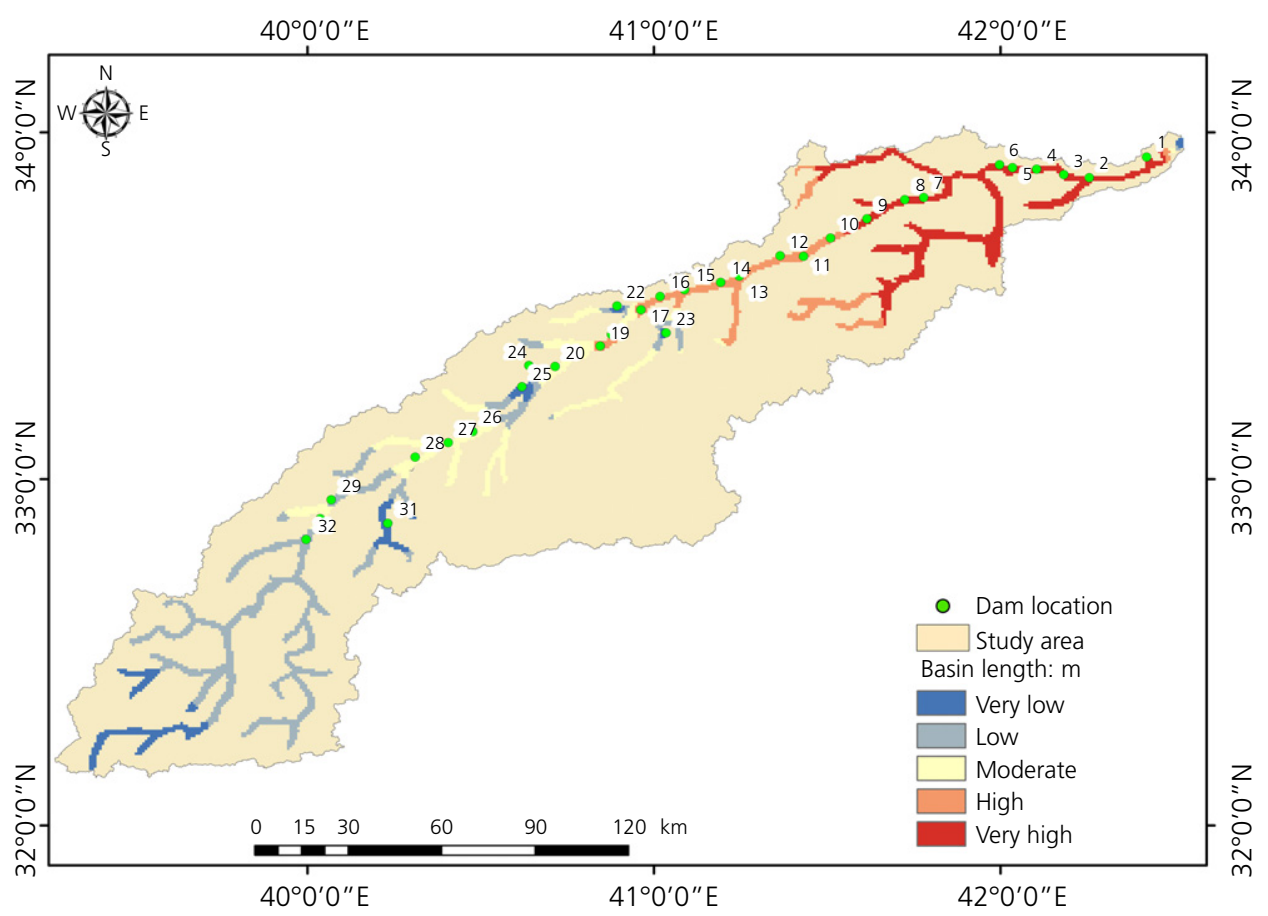

(b)

Figure 7. Thematic maps of (a) basin slope and (b) basin length. A full-colour version of this figure can be found on the ICE Virtual Library (www.icevirtuallibrary.com)

$\left(>10000 \mathrm{~km}^{2}\right)$. The map indicates that the very high class of the basin area is in the northeast of the study area. The areas with very low basin area $\left(<100 \mathrm{~km}^{2}\right)$ occur in different areas of the study area. The southwestern part of the study area comprises a large portion of low basin areas, with moderate and high basin area classes occurring in the central part. 
Table 2. Ranking and weighting of criteria and their influence class used for mapping RWH site potential

\begin{tabular}{|c|c|c|c|c|c|c|c|c|c|c|c|c|c|c|c|c|c|c|c|}
\hline \multirow[b]{2}{*}{ Site } & \multicolumn{2}{|c|}{$\begin{array}{l}\text { Annual } \\
\text { flood }\end{array}$} & \multicolumn{2}{|c|}{$\begin{array}{l}\text { Basin } \\
\text { area }\end{array}$} & \multicolumn{2}{|c|}{$\begin{array}{l}\text { Basin } \\
\text { length }\end{array}$} & \multicolumn{2}{|c|}{$\begin{array}{l}\text { Basin } \\
\text { slope }\end{array}$} & \multicolumn{2}{|c|}{$\begin{array}{c}\text { Maximum } \\
\text { flow distance }\end{array}$} & \multicolumn{2}{|c|}{$\begin{array}{c}\text { Drainage } \\
\text { frequency density }\end{array}$} & \multicolumn{2}{|c|}{$\begin{array}{l}\text { Stream } \\
\text { order }\end{array}$} & \multicolumn{2}{|c|}{$\begin{array}{l}\text { Lineament } \\
\text { frequency density }\end{array}$} & \multirow[b]{2}{*}{$w_{\mathrm{c}}$} & \multirow[b]{2}{*}{$\sum R_{\mathrm{c}} \times W_{\mathrm{c}}$} & \multirow[b]{2}{*}{$\sum\left(R_{\mathrm{c}} \times W_{1 / v}\right.$} \\
\hline & $R_{\mathrm{c}}$ & $W_{1 / v}$ & $R_{\mathrm{c}}$ & $W_{1 / v}$ & $R_{\mathrm{c}}$ & $W_{1 / v}$ & $R_{\mathrm{c}}$ & $W_{1 / v}$ & $R_{\mathrm{c}}$ & $W_{1 / v}$ & $R_{\mathrm{c}}$ & $W_{1 / v}$ & $R_{\mathrm{c}}$ & $W_{1 / v}$ & $R_{\mathrm{c}}$ & $W_{1 / v}$ & & & \\
\hline 1 & 90 & 0.12 & 90 & 0.15 & 90 & 0.13 & 30 & $0 \cdot 11$ & 90 & $0 \cdot 13$ & 30 & 0.13 & 90 & $0 \cdot 17$ & 50 & 0.06 & 0.125 & 70 & 74 \\
\hline 2 & 90 & 0.12 & 90 & 0.15 & 90 & 0.13 & 30 & $0 \cdot 11$ & 90 & $0 \cdot 13$ & 30 & $0 \cdot 13$ & 90 & $0 \cdot 17$ & 50 & 0.06 & 0.125 & 70 & 74 \\
\hline 3 & 90 & 0.12 & 90 & 0.15 & 90 & 0.13 & 30 & 0.11 & 90 & 0.13 & 30 & 0.13 & 90 & 0.17 & 50 & 0.06 & 0.125 & 70 & 74 \\
\hline 4 & 90 & 0.12 & 90 & 0.15 & 90 & 0.13 & 30 & 0.11 & 90 & $0 \cdot 13$ & 30 & 0.13 & 90 & 0.17 & 50 & 0.06 & 0.125 & 70 & 74 \\
\hline 5 & 90 & 0.12 & 90 & 0.15 & 90 & 0.13 & 30 & $0 \cdot 11$ & 90 & $0 \cdot 13$ & 30 & $0 \cdot 13$ & 90 & $0 \cdot 17$ & 50 & 0.06 & 0.125 & 70 & 74 \\
\hline 6 & 90 & 0.12 & 90 & 0.15 & 90 & 0.13 & 30 & 0.11 & 90 & 0.13 & 50 & 0.13 & 90 & 0.17 & 50 & 0.06 & 0.125 & 73 & 76 \\
\hline 8 & 90 & 0.12 & 90 & 0.15 & 90 & 0.13 & 30 & 0.11 & 90 & 0.13 & 50 & 0.13 & 90 & 0.17 & 70 & 0.06 & 0.125 & 75 & 78 \\
\hline 9 & 70 & 0.12 & 70 & 0.15 & 90 & 0.13 & 30 & $0 \cdot 11$ & 70 & $0 \cdot 13$ & 50 & 0.13 & 90 & 0.17 & 50 & 0.06 & 0.125 & 65 & 68 \\
\hline 10 & 70 & 0.12 & 70 & 0.15 & 70 & 0.13 & 30 & $0 \cdot 11$ & 70 & $0 \cdot 13$ & 50 & 0.13 & 90 & $0 \cdot 17$ & 70 & 0.06 & 0.125 & 65 & 67 \\
\hline 11 & 70 & 0.12 & 70 & 0.15 & 70 & 0.13 & 30 & 0.11 & 70 & 0.13 & 70 & 0.13 & 90 & 0.17 & 70 & 0.06 & 0.125 & 68 & 70 \\
\hline 12 & 70 & 0.12 & 70 & 0.15 & 70 & 0.13 & 30 & $0 \cdot 11$ & 70 & $0 \cdot 13$ & 70 & $0 \cdot 13$ & 90 & $0 \cdot 17$ & 50 & 0.06 & 0.125 & 65 & 68 \\
\hline 13 & 70 & 0.12 & 70 & 0.15 & 70 & 0.13 & 30 & 0.11 & 70 & 0.13 & 70 & 0.13 & 90 & 0.17 & 50 & 0.06 & 0.125 & 65 & 68 \\
\hline 14 & 70 & 0.12 & 70 & 0.15 & 70 & 0.13 & 30 & $0 \cdot 11$ & 70 & $0 \cdot 13$ & 70 & 0.13 & 90 & 0.17 & 30 & 0.06 & 0.125 & 63 & 67 \\
\hline 15 & 70 & 0.12 & 70 & 0.15 & 70 & 0.13 & 30 & $0 \cdot 11$ & 70 & $0 \cdot 13$ & 70 & 0.13 & 90 & $0 \cdot 17$ & 30 & 0.06 & 0.125 & 63 & 67 \\
\hline 16 & 70 & 0.12 & 70 & 0.15 & 70 & 0.13 & 30 & $0 \cdot 11$ & 70 & $0 \cdot 13$ & 70 & 0.13 & 90 & 0.17 & 30 & 0.06 & 0.125 & 63 & 67 \\
\hline 17 & 50 & 0.12 & 70 & 0.15 & 70 & 0.13 & 30 & $0 \cdot 11$ & 70 & $0 \cdot 13$ & 70 & $0 \cdot 13$ & 90 & $0 \cdot 17$ & 30 & 0.06 & 0.125 & 60 & 65 \\
\hline 19 & 50 & 0.12 & 70 & 0.15 & 70 & 0.13 & 50 & $0 \cdot 11$ & 50 & $0 \cdot 13$ & 70 & 0.13 & 90 & 0.17 & 10 & 0.06 & 0.125 & 58 & 63 \\
\hline 20 & 50 & 0.12 & 50 & 0.15 & 70 & $0 \cdot 13$ & 50 & $0 \cdot 11$ & 50 & $0 \cdot 13$ & 70 & $0 \cdot 13$ & 90 & $0 \cdot 17$ & 10 & 0.06 & 0.125 & 55 & 60 \\
\hline 21 & 50 & 0.12 & 50 & 0.15 & 70 & 0.13 & 50 & $0 \cdot 11$ & 50 & 0.13 & 70 & 0.13 & 90 & 0.17 & 10 & 0.06 & 0.125 & 55 & 60 \\
\hline 22 & 10 & 0.12 & 10 & 0.15 & 30 & 0.13 & 30 & $0 \cdot 11$ & 10 & $0 \cdot 13$ & 10 & 0.13 & 30 & $0 \cdot 17$ & 50 & 0.06 & 0.125 & 23 & 21 \\
\hline 23 & 10 & 0.12 & 10 & 0.15 & 30 & 0.13 & 10 & 0.11 & 10 & 0.13 & 10 & 0.13 & 30 & $0 \cdot 17$ & 90 & 0.06 & 0.125 & 25 & 22 \\
\hline 24 & 10 & 0.12 & 10 & 0.15 & 30 & 0.13 & 50 & $0 \cdot 11$ & 10 & $0 \cdot 13$ & 10 & $0 \cdot 13$ & 30 & $0 \cdot 17$ & 90 & 0.06 & 0.125 & 30 & 26 \\
\hline 25 & 30 & 0.12 & 10 & 0.15 & 30 & 0.13 & 70 & $0 \cdot 11$ & 10 & 0.13 & 10 & 0.13 & 50 & 0.17 & 90 & 0.06 & 0.125 & 38 & 34 \\
\hline 26 & 50 & 0.12 & 50 & 0.15 & 50 & 0.13 & 50 & $0 \cdot 11$ & 30 & $0 \cdot 13$ & 70 & 0.13 & 50 & 0.17 & 70 & 0.06 & 0.125 & 53 & 52 \\
\hline 27 & 50 & 0.12 & 50 & 0.15 & 50 & 0.13 & 50 & $0 \cdot 11$ & 30 & $0 \cdot 13$ & 70 & 0.13 & 70 & 0.17 & 70 & 0.06 & 0.125 & 55 & 55 \\
\hline 28 & 50 & 0.12 & 30 & 0.15 & 50 & 0.13 & 70 & 0.11 & 30 & 0.13 & 70 & 0.13 & 70 & 0.17 & 50 & 0.06 & 0.125 & 53 & 53 \\
\hline 29 & 50 & 0.12 & 30 & 0.15 & 50 & 0.13 & 90 & $0 \cdot 11$ & 30 & $0 \cdot 13$ & 70 & $0 \cdot 13$ & 70 & $0 \cdot 17$ & 70 & 0.06 & 0.125 & 58 & 57 \\
\hline 30 & 30 & 0.12 & 30 & 0.15 & 50 & 0.13 & 90 & $0 \cdot 11$ & 30 & $0 \cdot 13$ & 90 & $0 \cdot 13$ & 70 & $0 \cdot 17$ & 90 & 0.06 & 0.125 & 60 & 58 \\
\hline 31 & 30 & 0.12 & 30 & 0.15 & 10 & 0.13 & 10 & $0 \cdot 11$ & 10 & $0 \cdot 13$ & 70 & $0 \cdot 13$ & 50 & $0 \cdot 17$ & 90 & 0.06 & 0.125 & 38 & 36 \\
\hline 32 & 30 & 0.12 & 10 & 0.15 & 30 & 0.13 & 90 & 0.11 & 30 & 0.13 & 50 & 0.13 & 50 & $0 \cdot 17$ & 90 & 0.06 & 0.125 & 48 & 44 \\
\hline
\end{tabular}




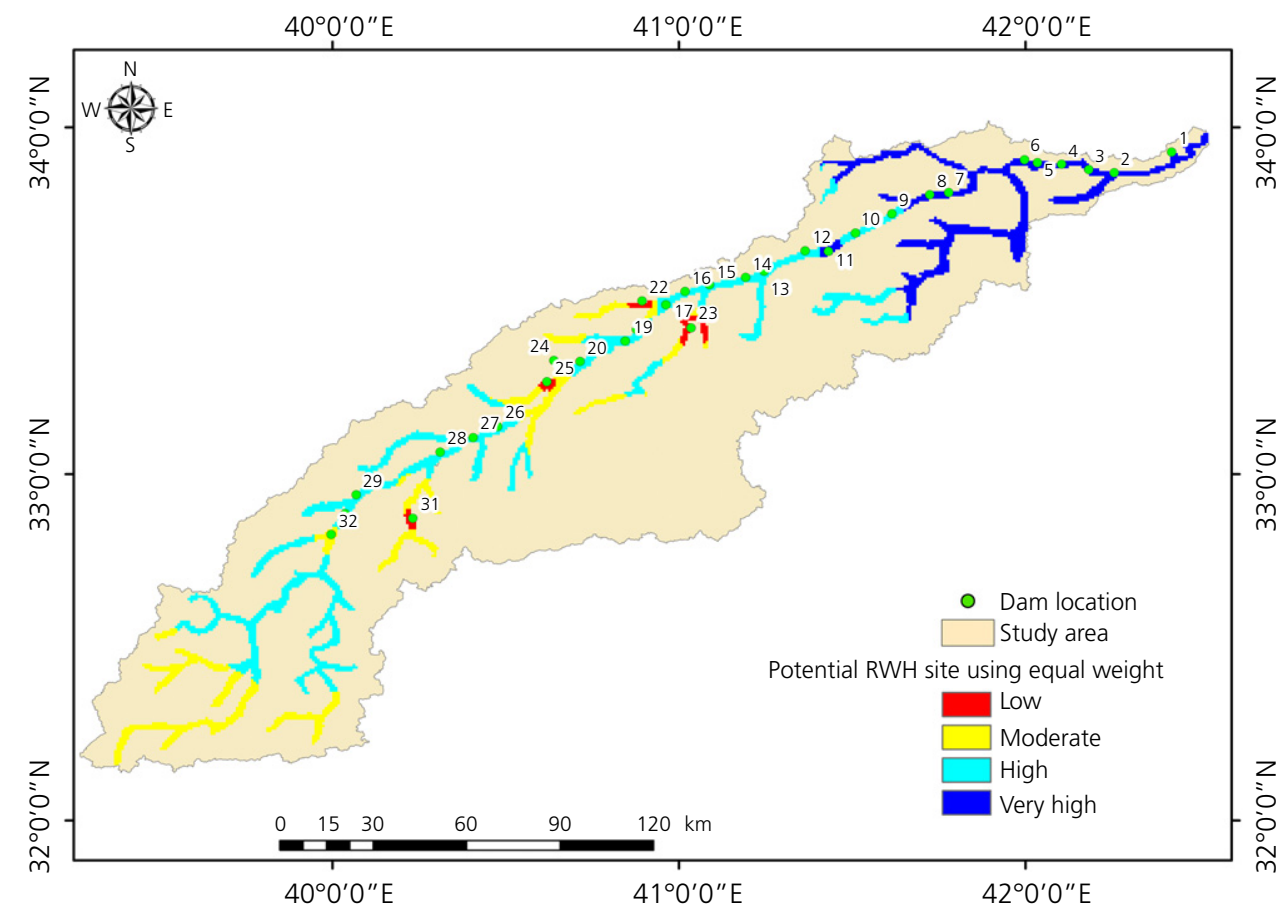

(a)

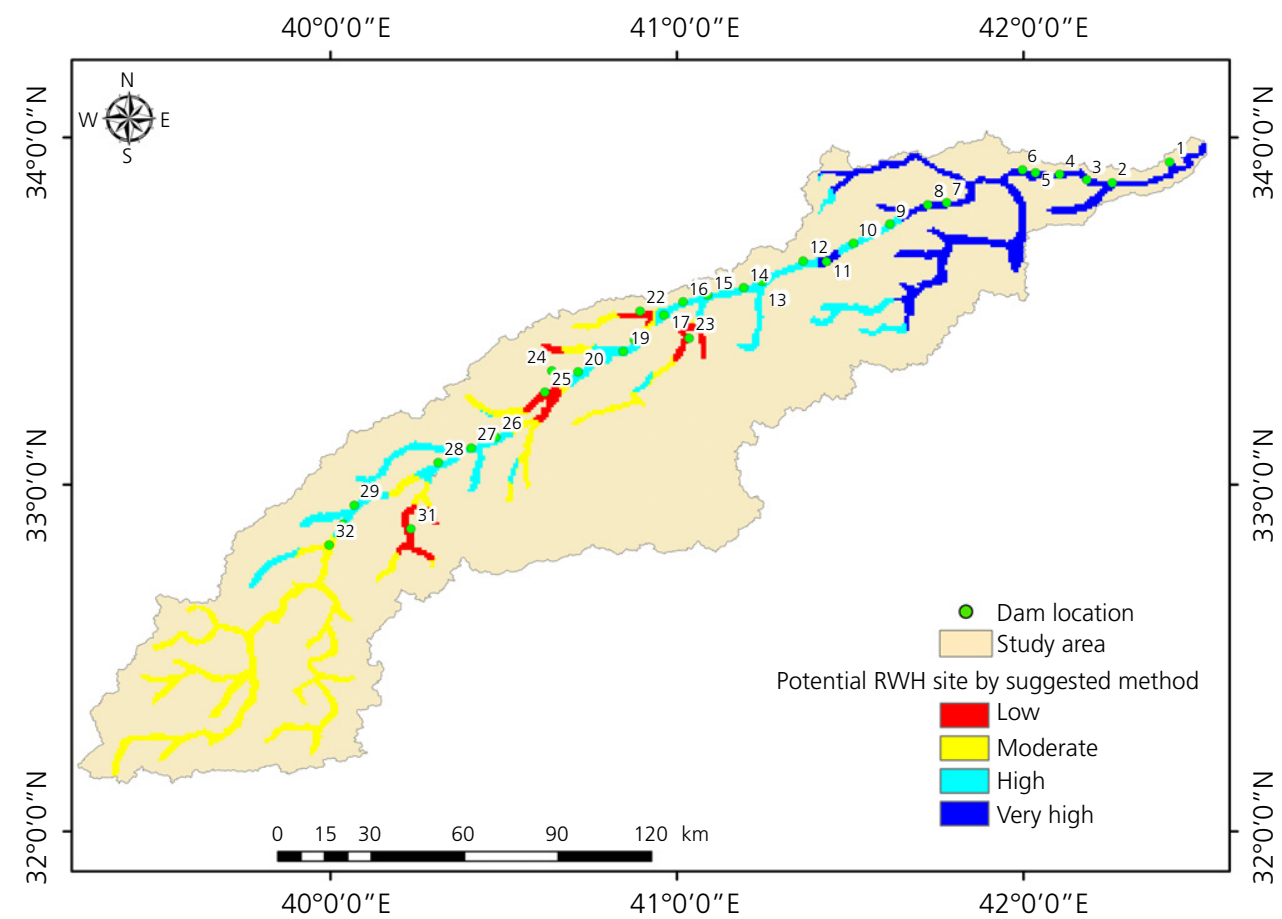

(b)

Figure 8. Thematic maps displaying potential sites for RWH using (a) equal weight and (b) statistical weight. A full-colour version of this figure can be found on the ICE Virtual Library (www.icevirtuallibrary.com)

\subsection{Basin slope}

The gradient of the drainage basin, or basin slope, is a key issue in the selection of sites for maximum storage capacity for water harvesting. A high basin slope results in a shorter time of concentration of peak flow. The channel slope is the most significant criterion in determining water infiltration, with 
channel slope being inversely proportional to infiltration. Figure 7(a) shows the study region mapped into five slope classes, namely very low $(>0 \cdot 0205)$, low $(0 \cdot 0170-0 \cdot 0205)$, moderate (0.0152-0.0170), high $(0.0133-0.0152)$ and very high $(<0.0133)$. High and very high slope classes occur in the southwestern part of the study area. A decrease in slope (moderate class) is observed slightly further north. The central and northeastern parts of the study area comprise very low and low classes of basin slope.

\subsection{Basin length}

Basin length is defined as the distance through which a basin is cut into two similar sectors (Horton, 1945). Basin length plays an important role in predicting the chances of the basin being flooded: the longer the basin length, the lower the probability of flooding in the basin. Therefore, the longer the basin length with a lower slope, the higher the potential for RWH. Macro-catchment procedures for water harvesting are more effective in longer basins, while micro-catchment techniques are more appropriate for shorter basins. The resulting thematic map of basin length is shown in Figure 7(b), with five classes of basin length: very low (<71 $500 \mathrm{~m})$, low (71 500-122 $000 \mathrm{~m})$, moderate (122 000-192000 m), high (192 000-270 $000 \mathrm{~m})$ and very high $(>270000 \mathrm{~m})$. The map indicates that sites with very low and low basin length are in the southwestern part of the study area, with very high and high classes in the northeastern part.

\subsection{Selecting criteria weights}

A key part of this investigation was to identify potential RWH sites that were rated and categorised utilising the eight thematic maps demonstrating the influence of different criteria on RWH. The criteria were therefore classified into five divisions, from those with very high influence to very low influence.

In order to achieve ranking and classification, each site was scored by the summation of the rank average multiplied by the weight of each criterion (Table 2). The highest summation is ranked first. Based on the two methods of weighting the criteria (equal weight $\left(W_{\mathrm{c}}\right)$ and statistical weight $\left.\left(W_{1 / v}\right)\right)$, the summation results for the 32 selected sites were categorised into four classes: <30 (low), 30-50 (moderate), 51-69 (high) and $>69$ (very high). Two output maps were constructed using a GIS platform based on the two weighting methods ( $W_{\mathrm{c}}$ and $W_{1 / v}$ ). Figures 8(a) and 8(b) show the sites across the region classified as having low, moderate, high and very high RWH potential. The two output maps show that the proposed method (based on $W_{1 / v}$ ) is consistent with the first method (based on $W_{\mathrm{c}}$ ) and is thus an ideal method for identifying the potential of RWH sites.

\section{Conclusion}

In this work, the contemporary examination methods of WMS, GIS and remote sensing techniques were used in an investigative process, as well as in modelling and mapping.
A combination of these tools was used to develop a methodology to rank and identify potential sites for RWH in Wadi Horan valley, located in Iraq's western desert. Sites across the entire region were classified as having low, moderate, high or very high RWH potential. Sites with very high potential were identified in $25 \%$ of the study area, with $53 \%, 13 \%$ and $9 \%$ of the study area identified as having high, moderate and low potential, respectively. The sites identified as having very high, high and moderate RWH potential are promising for the provision of water along the catchment, and could be investigated further using other qualitative and quantitative criteria in order to define suitable sites for realising water harvesting in finer detail.

In conclusion, through the application of WMS, GIS and remote sensing techniques, this paper proposes a methodology for improved water resources management and the sustainable development of arid regions through the identification of potential RWH sites.

\section{Acknowledgement}

The authors thank the Ministry of Education, Malaysia, for financial support through the Fundamental Research Grant Scheme (FRGS) (grant number FRGS/2/2014/ TK02/UKM/03/2).

\section{REFERENCES}

Aher PD, Adinarayana J and Gorantiwar SD (2013) Prioritization of watersheds using multi-criteria evaluation through fuzzy analytical hierarchy process. Agricultural Engineering International: CIGR Journal 15(1): 11-18.

Adham A, Riksen M, Ouessar M and Ritsema C (2016) Identification of suitable sites for rainwater harvesting structures in arid and semiarid regions: A review. International Soil and Water Conservation Research 4(2): 108-120.

Ashmawy MH, Swedan AH and Abdel-Fattah T (2000) Flash flood hazards of drainage basins of Sinai Peninsula. Annals of the Geological Survey of Egypt 23: 467-489.

Bonacci O, Jukić D and Ljubenkov I (2006) Definition of catchment area in karst: case of the rivers Krčić and Krka, Croatia. Hydrological Sciences Journal 51(4): 682-699.

Chowdary VM, Ramakrishnan D, Srivastava YK, Chandran V and Jeyaram A (2009) Integrated water resource development plan for sustainable management of Mayurakshi Watershed, India using remote sensing and GIS. Water Resources Management 23(8): 1581-1602.

Elewa H, Qaddah A and El-Fel A (2012) Determining potential sites for runoff water harvesting using remote sensing and geographic information systems-based modeling in Sinai. American Journal of Environmental 8(8): 42-55.

El Shamy IZ (1992) Towards the water management in Sinai Peninsula. Proceedings of the 3rd Conference on Geology of Sinai Development, Ismailia, Egypt, pp. 63-70.

Gregory KL and Walling DE (1985) Drainage basin from and process: a geomorphological approach. Science 184(4140): 458.

Grohmann CH (2004) Morphometric analysis in geographic information systems: applications of free software Grass and R. Computers and Geosciences 30(9-10): 1055-1067. 
Hogarth WL, Parlangeb JY, Rosec CW et al. (2004) Soil erosion due to rainfall impact with inflow: an analytical solution with spatial and temporal effects. Journal of Hydrology 295(1-4): 140-148.

Horton RE (1945) Erosional development of streams and their drainage basins; hydrophysical approach to quantitative morphology. Geological Society of America Bulletin 56(1): 151-180.

Jain V and Sinha R (2003) Evaluation of geomorphic control on flood hazard through geomorphic instantaneous unit hydrograph. Current Science 85(11): 1596-1600.

Jamali IA, Mörtberg U, Olofsson B and Shafique M (2014) A spatial multi-criteria analysis approach for locating suitable sites for construction of subsurface dams in Northern Pakistan. Water Resources Management 28(14): 5157-5174.

Javed A, Khanday MY and Rais S (2011) Watershed prioritization using morphometric and land use/land cover parameters: a remote sensing and GIS based approach. Journal of the Geological Society of India 78(1): 63-75.

Jha MK, Chowdary VM, Kulkarni Y and Mal BC (2014) Rainwater harvesting planning using geospatial techniques and multicriteria decision analysis. Resources, Conservation and Recycling $\mathbf{8 3}$ 96-111.

Kadam AK, Kale SS, Pande NN, Pawar NJ and Sankhua RN (2012) Identifying potential rainwater harvesting sites of a semi-arid, basaltic region of western India, using SCS-CN method. Water Resources Management 26(9): 2537-2554.

Kamel A and Mohammed A (2010) Determination of water harvesting regions in Iraqi western desert using GIS system. Iraqi Journal of Desert Studies, Special Issue of 1st Scientific Conference 2(2): $33-42$.

Kanth TA (2010) Prioritization of watersheds in Wular catchment for sustainable development and management of natural resources. Recent Research in Science and Technology 2(4): 12-16.

Krois J and Schulte A (2014) GIS-based multi-criteria evaluation to identify potential sites for soil and water conservation techniques in the Ronquillo watershed, northern Peru. Applied Geography 51(7): 131-142.

Mahmoud SH (2014) Delineation of potential sites for groundwater recharge using a GIS-based decision support system. Environmental Earth Sciences 72(9): 3429-3442.

Maidment DR (1992) Handbook of Hydrology. McGraw-Hill, New York, NY, USA.

Mohd Hasmadi I, Pakhriazad HZ and Mohamad FS (2010). Geographic information system-allocation model for forest path: a case study in Ayer Hitam Forest Reserve, Malaysia. American Journal of Applied Sciences 7(3): 376-380.

Nooka Ratnam K, Srivastava YK, Venkateswara Rao V, Amminedu E and Murthy KSR (2005) Check dam positioning by prioritization microwatersheds using SYI model and morphometric analysis - remote sensing and GIS perspective. Journal of the Indian Society of Remote Sensing 33(1): 25-38.

Pandey A, Chowdary VM, Mal BC and Dabral PP (2011) Remote sensing and GIS for identification of suitable sites for soil and water conservation structures. Land Degradation and Development 22(3): $359-372$

Pitlick J (1994) Relation between peak flows, precipitation, and physiography for five mountainous regions in the western USA. Journal of Hydrology 158(3-4): 219-240.

Rahaman SA, Ajeez SA, Aruchamy S and Jegankumar R (2015) Prioritization of sub watershed based on morphometric characteristics using fuzzy analytical hierarchy process and geographical information system - a study of Kallar watershed, Tamil Nadu. Aquatic Procedia 4: 1322-1330, https://doi.org/10. 1016/j.aqpro.2015.02.172.

Reij C, Mulder P and Begemann L (1990) Water harvesting for plant production. Applied Geography 10(4): 359
Sadrolashrafi SS, Mohamed TA, Mahmud ARB, Kholghi MK and Samadi A (2008). Integrated modeling for flood hazard mapping using watershed modeling system. American Journal of Engineering and Applied Sciences 1(2): 149-156.

Sarma S and Saikia T (2012) Prioritization of Sub-watersheds in Khanapara - Bornihat Area of Assam - Meghalaya (India) based on land use and slope analysis using remote sensing and GIS. Journal of the Indian Society of Remote Sensing 40(3): 435-446.

Sayl KN, Muhammad NS, Yaseen ZM and El-shafie A (2016) Estimation the physical variables of rainwater harvesting system using integrated GIS-based remote sensing approach. Water Resources Management 30(9): 3299-3313.

Sayl KN, Muhammad NS and El-Shafie A (2017) Optimization of areavolume-elevation curve using GIS-SRTM method for rainwater harvesting in arid areas. Environmental Earth Sciences 76(10): $368-300$.

Singh S (1994) Remote-sensing in the evacuation of morphohydrological characteristics of the drainage basins of the Jojri catchment. Annals of Arid Zone 33(4): 273-278.

Suresh M, Sudhakar S, Tiwari KN and Chowdary VM (2004) Prioritization of watersheds using morphometric parameters and assessment of surface water potential using remote sensing. Journal of the Indian Society of Remote Sensing 32(3): 249-259.

Taffere GR, Beyene A, Vuai SAH, Gasana J and Seleshi Y (2016) Characterization of atmospheric bulk deposition: implications on the quality of rainwater harvesting systems in the semi-arid city of Mekelle, northern Ethiopia. Environmental Processes 3(1): 247-261.

Thakkar AK and Dhiman SD (2007) Morphometric analysis and prioritization of miniwatersheds in Mohr watershed, Gujarat using remote sensing and GIS techniques. Journal of the Indian Society of Remote Sensing 35(4): 313-321.

Tyagi JV, Mishra SK, Singh R and Singh VP (2008) SCS-CN based time-distributed sediment yield model. Journal of Hydrology 352(3-4): 388-403.

\section{How can you contribute?}

To discuss this paper, please email up to 500 words to the editor at journals@ice.org.uk. Your contribution will be forwarded to the author(s) for a reply and, if considered appropriate by the editorial board, it will be published as discussion in a future issue of the journal.

Proceedings journals rely entirely on contributions from the civil engineering profession (and allied disciplines). Information about how to submit your paper online is available at www.icevirtuallibrary.com/page/authors, where you will also find detailed author guidelines. 